\title{
Die kontekstuele funksie van Hebreërs 13:8
}

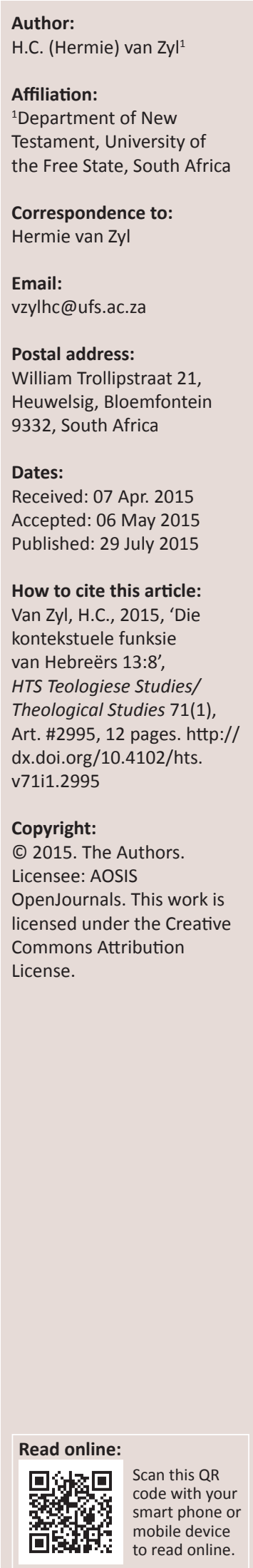

The contextual function of Hebrews 13:8. In this article the contextual function of Hebrews 13:8 is investigated. This verse is rather enigmatic as regards its meaning and contextual function. Scholars usually find that verse 8 combines with the immediately preceding and following verses, that is, verses 7 and 9, but the rest of the chapter is seldom brought into play. This article attempts to address this deficiency. It is proposed that verse 8 plays the following role in Chapter 13: It supports the teaching and life of the spiritual leaders, counteracts false teachings, provides stability for the readers' pilgrimage in this life, and serves as the Christological basis of the community's worship.

\section{Inleiding}

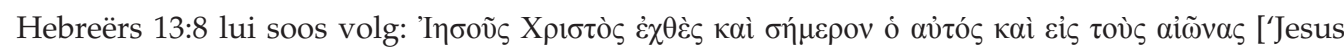
Christus is gister en vandag dieselfde en tot in ewigheid ${ }^{1}{ }^{1}$. Die funksie wat Hebreërs 13:8 in sy konteks ${ }^{2}$ vervul, is nie onmiddellik duidelik nie. Attridge (1989:392) wys byvoorbeeld daarop dat vers 8 formeel onverbonde is met wat dit voorafgaan en wat daarop volg. Dit beteken dat


van hoe hierdie vers met sy konteks skakel nie. Verder pas vers 8 met die eerste oogopslag ook nie inhoudelik by verse 7 en 9 nie. Die leser moet gevolglik sy eie afleidings uit die argument van Hebreërs 13 maak oor hoe vers 8 met sy tekstuele omgewing skakel. Die meeste navorsers doen wel aan die hand dat vers 8 'n retoriese verband met sy onmiddellike omgewing - vers 7 en vers $9-$ het $^{3}$ (kyk latere afdelings vir meer besonderhede), maar dit is waar dit eindig. Wat die res van Hebreërs 13 betref, gee navorsers selde 'n aanduiding of, en indien wel, watter rol vers 8 in die argument vervul. Dit is gevolglik die oogmerk van hierdie artikel om dié gebrek reg te stel. Afgesien van die skakeling met 13:7 en 9 wil die artikel aantoon dat 13:8 'n integrale funksie vervul in die argument van Hebreërs 13, ten minste tot en met 13:19. Let wel, die oogmerk is nie soseer om met nuwe eksegetiese insigte vorendag te kom nie, maar om binne die raamwerk van bestaande eksegese aan te toon dat Hebreërs 13:8 'n wyer rol te vervul het as wat eksegete normaalweg daaraan toeken.

Die artikel verloop soos volg: Eers word gelet op die outentisiteit van Hebreërs 13 - of dit 'n losstaande aanhangsel is en of dit ' $n$ integrale deel van Hebreërs vorm. Vervolgens word die oorhoofse struktuur en argument van Hebreërs 13 behandel, en laastens word aangetoon watter funksie 13:8 in die argument van Hebreërs 13 vervul en wat die elemente hiervan is.

\section{Hebreërs 13 se verband met Hebreërs 1-12}

Vir die funksie van Hebreërs 13:8 binne hoofstuk 13 is dit belangrik om te besluit of hierdie hoofstuk 'n losstaande aanhangsel tot die Hebreërgeskrif is en of dit 'n integrale deel van Hebreërs uitmaak. Indien laasgenoemde die geval is, kan argumente aangevoer word dat 13:8 nie net ' $n$ bepaalde rol in hoofstuk 13 speel nie, maar dat die hele Hebreërgeskrif 'n invloed op die argument van Hebreërs 13 as konteks van 13:8 uitoefen.

Ouer eksegete, in die tyd van die hoogbloei van die Literarkritik rondom die eeuwisseling van die negentiende na die twintigste eeu (bv. Wrede en Torrey, soos aangehaal deur Jones 1985:398, 404), het maklik van die standpunt uitgegaan dat Hebreërs 13 'n latere toevoeging tot Hebreërs was - óf deur die Hebreërskrywer self óf deur 'n ander outeur. Die redes wat gewoonlik aangevoer is, was dat 12:25-29'n natuurlike afsluiting - 'n soort teologiese klimaks - vir Hebreërs

\footnotetext{
1.Waar vertalings vir die Grieks aangebied word, sal Die Nuwe Testament en Psalms - ' $n$ direkte vertaling (2014), ' $n$ projek van die Bybelgenootskap van Suid-Afrika, gevolg word, tensy anders vermeld.

2.Met konteks word in hierdie artikel primêr die tekstuele konteks van Hebreërs 13 bedoel. Die sosio-historiese konteks word uiteraard ook in ag geneem, maar die fokus is op die rol wat Hebreërs 13:8 in sy onmiddellike tekstuele omgewing vervul.

3.Selfs ouer kommentare soos dié van Moffat (1924:232) sien raak dat vers 8 skakel met wat dit voorafgaan en wat daarop volg.
} 
as homiletiese redevoering vorm. Verder het Hebreërs 13 'n taamlik abrupte begin; die laaste paar verse (22-25) vertoon beslis 'n groter briefkarakter as die begin of die liggaam van Hebreërs; allerlei persoonlike opmerkings oor die outeur en lesers duik nou op; die vermanings in die eerste ses verse van Hebreërs 13 is van 'n baie algemeen Christelike aard; daar is oor die algemeen 'n rustiger pastorale toon as die 'lewe-en-dood'-diskoers van Hebreërs 1-12; daar duik 'n verskeidenheid van nuwe temas op, soos 'n herderChristologie (13:20), en nie een hiervan word verder bespreek nie; en die woordeskat verskil ook aansienlik van die res van Hebreërs, waarskynlik vanweë die nuwe temas wat voorkom (vir bg. redes kyk bv. Filson 1967:14-15; Jones 1985:398; Wedderburn 2004:393-394). Hegermann (1988:266) wys ook op die ooreenkomste met die manier waarop Paulus sy briewe afsluit (katalogusagtige vermanings; slotgebed; seënwense; verwysing na medewerkers, in hierdie geval Timoteus), wat sommige navorsers (kyk by Attridge 1989:384) tot die slotsom laat kom het dat iemand hierdie hoofstuk bygevoeg het om Hebreërs in ooreenstemming te bring met die Pauliniese korpus, of, soos Steyn (2012:252) dit stel, om Pauliniese gesag aan die geskrif te verleen. ${ }^{4} \mathrm{Al}$ hierdie verskynsels laat Wedderburn (2004:394) opmerk: 'One is forced to ask: has the author who has so skilfully composed the preceding 12 chapters suddenly dropped a stitch?'

Ten spyte van bogenoemde voorbehoude is daar vandag redelik konsensus onder geleerdes dat Hebreërs 13 nie 'n losstaande byvoeging is nie, maar ' $n$ integrale deel van Hebreërs uitmaak, al is dit net weens 'n gebrek aan manuskripgetuienis tot die teendeel (Johnson 2001:76). Die debat word weliswaar nog gevoer oor die presiese aard van die skakeling van Hebreërs 13 met die res van Hebreërs. Op sy minste word gesê dat Hebreërs 1-12 die wyer konteks vorm waarteen Hebreërs 13 gelees moet word (Isaacs 1997:269), of dat Hebreërs 13 geskryf is met die kennis van Hebreërs 1-12 as agtergrond, hoewel laasgenoemde nie noodwendig met die oog op Hebreërs 13 as slot geskryf is nie (Wedderburn 2004:403-404). Verder word op die tematiese ooreenkomste tussen Hebreërs 13 en Hebreërs 1-12 gewys. Die treffendste ooreenkoms is die pelgrimsmotief wat so sterk in Hebreërs 1-12 figureer en wat ook in 13:11-16 opduik. Verdere ooreenstemmende motiewe is (vgl. Jones 1985:399): onsedelikheid en owerspel $(13: 4 ; 11: 25 ; 12: 16)$; liefde vir geld (13:5; 11:26); die vrese van die gelowige $(13: 6 ; 11: 23,27)$; die uniekheid van die verbond (13:20-21; 8:1-13; 10:1-18); en 'n voortsetting van dieselfde soort gebruik van die $\mathrm{Ou}$ Testament as in die res van Hebreërs - spesifiek 13:5-6, ${ }^{5}$ maar daar is ook aanduidings dat Ou-Testamentiese figure op dieselfde manier in 13:1-5 aangewend word as in Hebreërs

4.Steyn maak hierdie opmerking eintlik net ten opsigte van Hebreërs $13: 22-25$, maar dit kan uitgebrei word na die hele hoofstuk 13 indien die ander 'Pauliniese eienskappe' van Hebreërs 13, soos hierbo genoem, ook betrek word.

5.Johnson $(2003: 241,247)$ wys daarop dat die wêreld wat Hebreërs open, een is waar God Homself openbaar. Hebreërs haal dus die Ou Testament nie as Skrif van die ver hom die verlede aan nie, maar as God wat hier en nou praat. So word God se woord van dieverls 5 in diear na die Ou Tien on

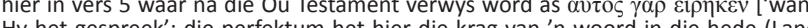
Hy het gespreek, die perfektum het hier die krag van ' $\mathrm{n}$ woord in die hede (Lane 1991:519)]. Die outeur konstrueer die aanhaling so dat dit 'n Godswoord aan sy tydgenote word (Attridge 1989:389; Guthrie 2003:274).
$1-12,{ }^{6}$ hoewel spesifieke name nie genoem word nie (Allen 2008:404-406). Attridge (1989:384) wys ook op die voor die hand liggende ooreenkoms tussen 13:7-19 en temas wat in voorafgaande hoofstukke voorkom. Filson (1967:27-81) toon uitvoerig aan hoe hierdie temas weerklank vind in die res van Hebreërs, soos 'gister' (13:8), 'altaar' (13:10), 'sondeoffer' (13:11-12), 'buite die kamp' (13:12-13), 'geen permanente stad nie' (13:14), en 'goed doen en mededeelsaam wees' (13:16).

Afgesien van die tematiese ooreenkomste wys navorsers ook op ooreenkomste in vorm en struktuur. Filson (1967:15-26) is op soek na die literêre vorm van Hebreërs 1-12 teenoor Hebreërs 13, maar vind dit moeilik om aparte vorme, soos homilie teenoor brief, te postuleer. Wat hy wel bereid is om te sê, is dat Hebreërs in sy geheel 'n skrywe is van 'n Christelike leier aan 'n gehoor wat bekend is met dié leier, en dat laasgenoemde ' $n$ dringende vermanende geskrif aan hulle rig. Filson vind verder 'n vierledige struktuur in Hebreërs 13, naamlik (1) gevarieerde onderrig, vermanings en inligting (13:1-19), (2) 'n formele seënbede (13:20-21), (3) verdere persoonlike inligting (13:22-24) en (4) 'n korter seënbede (13:25). Hy vergelyk hierdie struktuur met ander Nuwe-Testamentiese briewe en vind dieselfde patroon daar. Filson se punt is: hierdie struktuur wys dat Hebreërs 13 in pas is met die algemene destydse afsluiting van briewe aan gemeentes, en dat Hebreërs 13 dus nie van 'n ander hand hoef te kom as die outeur wat ook Hebreërs 1-12 geskryf het nie. En hoewel dit nie van die slothoofstuk verwag kan word om uitvoerig uit te wy oor vroeëre temas in die geskrif nie, kan wel aangetoon word dat die skrywer dieselfde temas aansny wat vroeër in die geskrif in meer besonderhede aan die orde was. (Filson wy vervolgens 'n paar afdelings aan hierdie ooreenstemmende temas.)

Weiss (1991:698-699), ook oortuig van die basiese eenheid tussen Hebreërs 1-12 en 13, probeer aantoon dat daar 'n strukturele verband tussen Hebreërs 12 en 13 is deurdat 12:28 (oproep tot dankbaarheid en dien van God met eerbied en ontsag) en 13:15-16 (oproep tot 'n lofoffer aan God) 'n omraming daarstel wat Hebreërs 13 'n soort konkretisering maak van die grondparanese vervat in 12:28 en 13:15-16. Hebreërs 13-ten minste totby vers 16-is dus'nuitbeelding van die oproep tot ware godsdiens. So gesien het Jones (1985:399) waarskynlik reg as hy sê dat ons in Hebreërs 12 reeds die finale klimaks van die Hebreërgeskrif het, met Hebreërs 13 'n voortgaande appèl wat met 'n seënbede afsluit.

Vir doeleindes van hierdie studie kan ons dus uitgaan van die standpunt dat Hebreërs 13 nie net die konteks van 13:8 vorm nie, maar dat dit ' $n$ integrale deel van Hebreërs uitmaak en dat die hele Hebreërs ' $n$ rol te speel het in die beredenering van die kontekstuele funksie van 13:8.

6.Steyn (2006) toon uitvoerig aan hoe die outeur in die manier waarop hy hier in 13:5-6 uit die Ou Testament aanhaal, sensitief is vir temas wat ' $n$ belangrike rol in Hebreërs speel, soos nuwe verbond, Sabbat en rusdag.

7.Wanneer gesê word dat dit die konsensus onder geleerdes vandag is dat Hebreërs 13 'n eenheid met Hebreërs 1-12 vorm, beteken dit nie dat daar nie steeds oor bepaalde dele van Hebreërs 13 se outentisiteit vrae is nie. Steyn (2012:251-253) is byvoorbeeld van mening dat daar goeie redes bestaan om 13:22-25 as 'n latere byvoeging tot Hebreërs 13 te beskou, deur die outeur self of ' $n$ ander outeur. 


\section{Struktuur en argument van Hebreërs 13}

In hierdie afdeling gaan dit oor die afbakening van 'n eenheid as konteks vir 13:8, asook om die verloop van die argument binne hierdie eenheid te bepaal.

In die vorige afdeling het ons reeds daarop gewys dat Filson 'n viervoudige struktuur vir Hebreërs 13 voorstel, te wete 1-19, 20-21, 22-24, 25. Lane (1991:506-507) is van mening dat hierdie indeling reg laat geskied aan die stilistiese eienskappe van Hebreërs 13 én aan die vloei van die argument binne hierdie hoofstuk. 'n Mens sou dus dié indeling as vertrekpunt kon neem vir die struktuur van Hebreërs 13, maar dit is nodig om verse 1-19 verder te onderverdeel.

Die meeste geleerdes beskou $13: 1-6^{8}$ as 'n aparte eenheid vanweë die opeenhoping van kort opdragte wat 'n verskeidenheid van algemeen etiese motiewe bevat. Voeg hierby die duidelike inclusio wat deur vers 7 en vers 17 gevorm word, dan is dit nóg 'n rede om verse 1-6 as 'n aparte eenheid van die res te onderskei. Die rede waarom die meeste geleerdes vers 7 en vers 17 as ' $n$ inclusio beskou (Attridge 1989:390-391; Braun 1984:457; Buchanan 1972:238; Lane 1991:526; Michel 1966:485; Weiss 1991:700), is vanweë die oproep in beide hierdie verse dat die gemeente hulle


hierdie waarneming voldoende om verse 7-17 as 'n eenheid naas verse 1-6 af te baken. Lane (1991:502-503) en Attridge (1989:390-391) is egter van opinie dat beide vers 7 en vers 17 bepaalde uitbreidings ondergaan wat meebring dat die inclusio of omraming na regte as die klusters verse 7-9 en verse 17-19 geneem moet word. Ek sluit my by hierdie siening aan. Verse 7-9 kan as 'n konsepsuele eenheid geneem word (Lane 1991:502, 528) deurdat dit die grond vir die kontinuering van die regte leer vorm: Die Woord van God is verkondig deur die gestorwe leiers (v. 7); hierdie Woord het gekristalliseer as 'n belydenisformule rondom die eintlike Leier, Jesus Christus (v. 8); maar nou word die belydenis skeefgetrek en bedreig deur vreemde leringe (v. 9). In vers 17 word die gemeente herinner aan die gemeente se leiers, maar hierdie keer die leiers wat nog lewe. Die gemeente word opgeroep om hulle leiers te gehoorsaam. In vers 18 vra die skrywer dat die gemeente vir hom en sy medewerkers moet bid, waaruit dit blyk dat die skrywer homself as een van die nog lewende leiers van die gemeente beskou. Die gebedsversoek van vers 18 word in vers 19 opgevolg met die rede waarom daar vir hom gebid moet word: sodat hy gou by die gemeente besoek kan aflê. ${ }^{9}$

\footnotetext{
8.Allen (2008:403-404) is uniek daarin om die eerste eenheid van Hebreërs 13 as verse $1-8$ te neem. Volgens Allen is dit die tema van kontinuïteit, getrouheid en onveranderlikheid wat hierdie eenheid bymekaar hou, met vers 1 (die broederliefde moet bly) en vers 8 (Christus is altyd dieselfde) wat die begin en afsluiting hiervan vorm. Ek vind dit egter moeilik om die gedagte van kontinuïteit as die draende tema van 13:1-8 te beskou, en Allen vind na my beste wete ook geen steun onder geleerdes vir hierdie indeling nie.

9.DeSilva (2000:507-508) erken dat daar baie daarvoor te sê is om verse 7-17 as ' $n$ afgeronde eenheid te neem, maar verkies om vers 17 by die volgende verse te groepeer vanweë die aandag wat hier gevra word vir die huidige leierskap in die gemeente. Afgesien van die gemeenteleiers (v. 17) is daar nog die outeur self en sy span (vv. 18-19, 22), God (vv. 20-21) en Timoteus (v. 23) wat belangrik is.
}

Wat tussen verse 7-9 en verse 17-19 lê, naamlik verse 10-16, is nie so maklik om te verstaan of struktureel te orden nie. Trouens, verskeie geleerdes (bv. Koester 1962:299; Young 2002:243) beskou hierdie verse as van die moeilikstes in die Nuwe Testament om te interpreteer. Ek sluit my egter by Lane (1991:526) aan wat daarop wys dat bogenoemde omramende klusters (vv. 7-9, vv. 17-19) die effek het dat verse 10-16 geaksentueer word, en wel so dat verse 10-12 (ons het ' $n$ altaar; die offerdiere se liggame word buite die kamp verbrand; Jesus ly buite die poort) die Christologiese begronding vir die verduidelikende oproep in verse 13-16 vorm (laat ons uitgaan na Hom toe; ons het hier nie 'n permanente stad nie; bring 'n lofoffer aan God). Lane stel ook 'n chiastiese struktuur vir verse 10-16 voor, wat die hegte samehang van hierdie verse verder beklemtoon:
A (13:10)

B (13:11)

C (13:12)

$C^{\prime}(13: 13) \quad$ Laat ons uitgaan na Jesus buite die kamp

B' (13:14) Ons het hier nie 'n permanente stad nie

$\mathrm{A}^{\prime}(13: 15-16)$
Dit bring ons by die laaste gedeelte van Hebreërs 13, te wete verse 20-25. Dit bestaan uit 'n seënbede (vv. 20-21) dat God die gelowiges deur Jesus Christus sal bekragtig tot ' $n$ lewe wat vir God welgevallig is, omraam deur 'n verwysing na die 'God van vrede' aan die begin en 'n doksologie gerig tot Jesus (of $\operatorname{God}^{10}$ ) aan die einde, en 'n 'amen' wat die gedeelte afsluit. Hoofstuk 13 word vervolgens beëindig met 'n laaste oproep (vv. 22-25) om vas te hou aan die 'woord van vermaning/bemoediging' (kennelik 'n verwysing na die hele Hebreërgeskrif), enkele persoonlike opmerkings, en 'n seëngroet. In die vorige afdeling is die integriteit en outentisiteit van Hebreërs 13 reeds bespreek. Dit is dus nie nodig om dit weer te beredeneer dat verse 20-25 'n integrale deel van Hebreërs 13 vorm nie. Tog is die toonaard en styl van verse $20-25$ van so ' $n$ aard dat dit as 'n aparte eenheid in die argument van Hebreërs 13 aangemerk kan word, tot so 'n mate dat sommige geleerdes (bv. Steyn 2012:251-253) selfs vermoed dat veral verse 22-25'n latere byvoeging tot Hebreërs 13 kan wees. Ons hoef laasgenoemde gedagte vir doeleindes van hierdie studie egter nie verder te voer nie.

Uit bogenoemde uiteensetting kan ons die gevolgtrekking maak dat Hebreërs 13 struktureel uit die volgende eenhede opgebou is: verse 1-6, 7-19, 20-25. Hoewel hulle binne 'n geintegreerde argument opereer, is die primêre eenheid waarbinne die funksie van Hebreërs 13:8 bepaal moet word, verse 7-19. Voordat oorgegaan word om die funksie van Hebreërs 13:8 binne hierdie eenheid te bespreek, sal ek met gebruikmaking van die strukturele elemente soos in hierdie

\footnotetext{
10. Hoewel dit die natuurlikste is om die persoonlike voornaamwoord $\tilde{\omega}$ se antesedent as Jesus te neem vanweë laasgenoemde se sintaktiese nabyheid (Attridge 1989:407-408), verkies DeSilva (2000:513) om die antesedent te sien as die subjek 1989:407-408), verkies DeSilva (2000:513) om die antesedent te sien as die subjek
van die seënbede wat in vers 20 begin, naamlik God. Hoe ook al - God of Jesus - dit maak nie veel verskil aan die omraming in verse 20-21 nie.
} 
afdeling geïdentifiseer, kortliks die oorhoofse argument van Hebreërs 13 probeer beskryf.

Ten einde die argument van Hebreërs 13 te beskryf, moet teruggegryp word na die verhouding tussen Hebreërs 13 en Hebreërs 1-12, soos in die vorige afdeling beredeneer. Dáár is genoem dat Hebreërs 13 nie 'n blote nagedagte is nie, maar vervleg is met die liggaam van die Hebreërgeskrif, en wel so dat dit die voorafgaande hoofstukke tot 'n klimaktiese afsluiting bring. Daar is ook op die tematiese ooreenkomste tussen Hebreërs 13 en die res van Hebreërs gewys. Hierdie tematiese vervlegting bring mee dat daar nie net een argument in Hebreërs 13 gevoer word nie, maar dat verskeie argumentslyne of trajekte van Hebreërs nou tot 'n afsluiting gebring word. Minstens drie trajekte kan onderskei word. Ek behandel hulle kortliks. ${ }^{11}$

Die trajek van ware aanbidding of ware godsdiens. Die gedagte dat Jesus as eenmalige, eindtydelike offer alle tydelike diereoffers tot ' $n$ einde gebring het en so die weg vir nuwe aanbiddingsvorme baan, geniet reg deur Hebreërs aandag. Dit word egter op 'n besondere manier weer deur 12:28 as beginpunt en 13:15-16, 21 as eindpunt aan die orde gestel (so Isaacs 1997:272; Lane 1991:498; Weiss 1991:697). Hebreërs 12:28 noem dat God op 'n welgevallige wyse ( $\varepsilon \dot{\alpha} \alpha \varepsilon^{\prime} \sigma \tau \omega \varsigma$ ) gedien moet word, en 13:21 sluit met dieselfde gedagte af, naamlik dat God deur Christus in ons bewerk wat voor God


konkrete terme uitgespel wat presies hierdie offers is wat vir God welbehaaglik is ( $\varepsilon \dot{\alpha} \alpha \rho \varepsilon \sigma \tau \varepsilon i \tau \alpha \iota)$, naamlik lofoffers, om goed te doen en om mededeelsaam te wees. Binne hierdie parameters verloop die argument in Hebreërs 13 soos volg (vgl. Lane 1991:506): verse 1-6 se etiese opdragte word saamgebind deur die kategorie van lofoffers, wat in 13:15-16 verder getipeer word. Verse 15-16 val egter binne die hegte eenheid van 13:10-16. Laasgenoemde eenheid word dus so die verdere tipering van die kultiese taal van 12:28 (om God op 'n welgevallige manier met eerbied en ontsag te dien). In groter besonderhede beteken dit dat die uitdrukking 'ons het 'n altaar' (v. 10) ondersteun word deur Jesus se offerdood ter wille van die sonde, waardeur die nuwe verbondsgemeente geheilig word vir diens aan God (13:12). Hierdie heiliging impliseer toegewyde dissipelskap (13:13-14), wat op sy beurt die moontlikheid open om aan God die offers te bring wat vir Hom welgevallig is (13:15-16). So bestaan die lewe binne die belydende gemeente uit dankbare diens aan God, wat weer terugspeel na 13:1-6. Die opdragte hier om broederliefde en gasvryheid te beoefen, wat ook inhou die versorging van die gevangenes (vv. 1-3), die opdrag om onsedelikheid, die besoedeling van die huwelik, asook om geldgierigheid te vermy (vv. 4-5), laasgenoemde omdat God Self hulle sekuriteit is (v. 6), is alles maniere waarop die gemeente God op die regte manier aanbid en dien. Die gebedswens, verse 20-21, gee vervolgens die versekering dat God Self die werk van gelowiges sal voltooi wat volgens sy wil geskied en vir

11. Weens die verskillende invalshoeke van hierdie trajekte mag dit wees dat die indelings wat genoem gaan word nie altyd presies ooreenstem met dié wat ek hierbo geïdentifiseer het nie. Hebreërs 13 is egter so ryk aan inhoud en die argument so dig verweef dat navorsers nie altyd die eenhede identies afbaken nie. Tog, oorhoofs gesien, is daar merkwaardige ooreenstemming.
Hom aanneemlik is. Voorts geskied hierdie beoefening van ware godsdiens onder toesig van die betroubare tradisie (v. 7) - waarvan Christus Self die waarborg is (v. 8) - en die huidige leierskap (vv. 17-19). Hebreërs 13:1-21 se funksie is dus om die implisiete opdrag vervat in 12:28 eksplisiet te maak. Dit gaan oor die heiliging van die gemeente in sy formele byeenkomste, maar ook in die private en openbare aspekte van hulle bestaan. En so word die argument van ware aanbidding en toewyding aan God op 'n kragtige manier tot afsluiting gebring in Hebreërs 13.

Die trajek van betroubare leierskap. Grässer (1992a:216) is van mening dat die lesers se verhouding tot hulle leiers die Leitmotiv van 13:7-24 vorm. Sooshierboberedeneer, vorm verse 7-9 en verse 17-19 die omraming van die argument in 13:719,12 wat, soos in die vorige paragraaf genoem, beklemtoon dat die godsdienstige lewe van die gemeente onder toesig van die leiers plaasvind. Leierskap in die gemeente staan egter nie los van die eintlike Leier, Jesus Christus nie. Een van die hooftemas van Hebreërs is juis om die unieke en superieure status van Jesus bo ander gesagsfigure uit die verlede en hede uit te beeld. Om hierdie rede word Jesus in 12:2 die Leidsman ( $\dot{\alpha} \rho \chi \eta \gamma o ́ \varsigma)$ en Voleinder ( $\tau \varepsilon \lambda \varepsilon 1 \omega \tau \eta \dot{s})$ van die geloof genoem. Dit is vir Hóm dat die gemeente in die oog moet hou en volg. Wanneer die gemeente dus in 13:7 opgeroep word om hulle gestorwe leiers ( $\dot{\eta} \gamma o v ́ \mu \varepsilon v o r)$ in gedagte te hou, en in 13:17 om hulle huidige leiers te gehoorsaam, is dit ten diepste Jesus as Leier wat agter die menslike leiers verrys. Soos Attridge (1989:392) dit stel: om aardse leiers te volg is om dié te volg wat vir Christus volg. Hebreërs 13:8 bevestig dan ook hierdie unieke posisie van Jesus: Hy is gister, vandag en tot in ewigheid dieselfde. Christus se onveranderlikheid het tot gevolg dat tweede geslag Christene dieselfde geloof as hulle voormalige leiers kan hê (Willis 1994:323). Via die ewigheid van Christus kan verskillende geslagte gelowiges dus vir mekaar tot voorbeeld wees (Braun 1984:459). Die verdere argument in verse 9-16 dien tot uitbouing van die unieke posisie van Jesus. Teenoor die verwarrende veelheid van vreemde leringe (v. 9) staan die onveranderlikheid van Jesus (v. 8). Hierdie onveranderlike algenoegsaamheid van Jesus se offer word vervolgens in verse 10-14 andermaal onderstreep: dit is sy offer wat die volk heilig (vv. 10-12) en die uitdaging tot hulle rig om Hom te volg in sy lyding (vv. 13-14). Dit alles kulmineer in 'n lewe van toewyding en diens (vv. 15-16). Die gedeelte sluit af deur, soos in vers 7, die gemeente weer eens op te roep om hulle aan hulle leiers te oriënteer (vv. 17-19).

Die trajek van 'n pelgrimsbestaan en -etiek. Die pelgrimsmotief is eweneens 'n belangrike tema in Hebreërs, veral in 3:7-4:11 en 11:1-12:2. Ook hierdie tema kom tot afsluiting in Hebreërs 13. Jones (1985:400-402) beskou daarom dié hoofstuk as die finale appèl tot ' $n$ pelgrimsbestaan. Die pelgrimsmotief en -bestaan kom die sigbaarste na vore in 13:13-14. In hierdie verse word die gemeente uitgenooi om na Jesus buite die

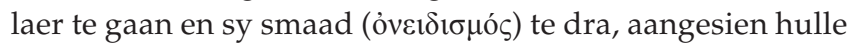

12. Hoewel Grässer die eenheid neem tot by vers 24 , omdat die leiers ook in laasgenoemde vers genoem word, neem ek die eenheid net tot by vers 19 vanweë die verskil in toonaard vanaf 13:20 (seënbede en laaste persoonlike opmerkings). 
hier nie 'n blywende stad het nie, synde op soek na die toekomstige stad. Dit is duidelik pelgrimstaal, wat mense oproep om die veiligheid van die bekende en vertroude agter te laat ter wille van die onsekerheid van 'n lewe saam met Jesus wat allerlei vorme van lyding en aanvegtinge inhou. ${ }^{13}$ Die beeld wat ons van die lesers in Hebreërs kry, is inderdaad dié van ontheemde mense, ' $\mathrm{n}$ volk in die woestyn (3:7-4:11; 12:18-29). Nou word hulle vir die laaste keer uitgedaag om 'n pelgrimsbestaan as permanente status te aanvaar, omdat dit die aard van geloof is om in hierdie wêreld outsiders te wees (vgl. Thompson 2011:209). Weens die vervlegtheid van die argument in Hebreërs 13 kom die pelgrimsmotief nie net in verse $13-14$ voor nie, maar spoel dit oor na die hele hoofstuk. So wys Thompson (2011: 212-214) daarop dat 13:10 ('ons het 'n offeraltaar waarvan dié wat in die tabernakel diens verrig, nie mag eet nie') reeds die insiders van die outsiders afgrens. Die insiders (dié wat in die tabernakel diens doen) word die outsiders, terwyl die outsiders (hulle wat ' $n$ alternatiewe offeraltaar het in Jesus $^{14}$ ) deel van die allerlaaste werklikheid word. Die leiers in die gemeente $(13: 7,17)$ wat hulle gesag aan Christus ontleen, word ook leiers van 'n ander werklikheid. Selfs die etiese opdragte van 13:1-6 kry 'n ander karakter. Hulle is nie so tradisioneel en verteenwoordigend van 'n Christelikburgerlike moraal as wat dit met die eerste oogopslag voorkom nie. 'n Mens kan die opdragte van verse 1-6 wel 'n insiders-etiek noem, maar binne die argument van Hebreërs 13 is dit 'n insiders-etiek vir outsiders (Thompson 2011:213). Dit is naamlik die manier waarop die lesers van Hebreërs wat aan 'n ander simboliese werklikheid verbind is (om buite die kamp te leef), hulleself in hierdie wêreld handhaaf. Elkeen van hierdie deugde - broederliefde; gasvryheid; versorging van gevangenes; 'n lewe vry van huweliksontrou, onsedelikheid en geldgierigheid - is die manier waarop die gelowiges sin en betekenis aan hulle pelgrimsbestaan in die wêreld gee. Hebreërs as teologiese berg baar dus nie ' $n$ etiese muis in 13:1-6 nie, maar daag die lesers juis daarmee uit tot die aanvaarding van hulle pelgrimstatus. Klauck (2006:418) deel hierdie standpunt. Volgens hom is die etiek van Hebreërs dié van 'n gemeente onder druk, 'n interim-etiek, bedoel vir mense op hulle pelgrimsreis na die hemelse stad, 'n etiek tussen nou en eendag, tussen onder en bo, 'n etiek van konstante liminaliteit, van 'n lewe op die rand van die afgrond. Hebreërs 13:1-6 se etiese aanmoedigings is dus almal daarop gemik om die onderlinge solidariteit in die gemeente te versterk en die grense teen die buitewêreld te trek (Klauck 2006:431, 437-440; ook DeSilva 2000:485-486). Dus, ook vanuit die pelgrimstema vertoon Hebreërs 13 'n geïntegreerde argument.

In hierdie afdeling het ek probeer aantoon hoe Hebreërs 13 opgebou is en wat die argumentslyne is wat deurloop, om daardeur 'n konteks vir Hebreërs 13:8 te probeer skep. Dit het duidelik geword dat 13:8 binne die eenheid 13:7-19, sy

13.Grässer (1992b:250) noem die 'uittrek uit die laer' die blywende Signatur van die Godsvolk, tot dit in die hemelse $\pi \alpha \tau \rho i ́ s$ tot rus kom

14.Kyk verder onder vir die betekenismoontlikhede van 13:10. plek vind en dat veral met drie argumentslyne rekening gehou moet word: dat die gemeente opgeroep word tot ware aanbidding en godsdiens, dat die leiers in ere gehou moet word vanweë hulle verbintenis met Christus, en dat die gemeente hulle verbintenis met Christus as 'n ander soort eksistensie in die wêreld moet beleef, naamlik as pelgrims op pad na die hemelse stad. Uiteraard kom hierdie drie argumentslyne as 'n geïntegreerde eenheid in Hebreërs 13 voor, maar genoemde drie lyne kan wel onderskei word. Wat nou oorbly, is om 13:8 se funksie binne hierdie konteks te beskryf.

\section{Die kontekstuele funksie van Hebreërs 13:8}

In die lig van die voorafgaande beredenerings is dit my kontensie dat Hebreërs 13:8 op 'n subtiele manier die teologiese ruggraat van die argument in Hebreërs 13 vorm. Dit speel 'n rol binne al drie argumentslyne soos in die vorige afdeling geïdentifiseer. Die kontekstuele funksie van 13:8 kan na my mening aan die hand van vier elemente beskryf word, hoewel hulle 'n geïntegreerde geheel vorm. Die eerste twee elemente hang saam met die argumentslyn van die leiers se posisie. Die derde element hou verband met die argumentslyn van die pelgrimsmotief, en die vierde element met die argumentslyn van ware godsdiens. Voor vers 8 se funksie bespreek word, word egter eers aandag aan vers 8 self gegee.

Geleerdes is dit eens dat die kernagtige formulering van vers 8 daarop dui dat dit in die vroeë kerk as 'n Christologiese belydenis in die algemeen en/of as formule in die erediensliturgie gedien het (so bv. Attridge 1989:392; Braun 1984:460; Jones 1985:400; Lane 1991:529; Loader 1981:83). Weiss (1991:715) maak ook 'n afleiding uit die feit dat Kodeks D 'n 'amen' tot die vers byvoeg: hoewel nie die beste lesing nie, dui dit wel op die aanvoeling by hierdie manuskriptradisie dat ons hier met ' $n$ liturgiese tradisie te doen het. Die vermoede bestaan verder dat die drieledige tydsaanduiding van die formule (gister, vandag, tot in ewigheid) verband hou met die omskrywing van God as die 'Een wat is, wat was en wat kom' in Openbaring 1:4, 8; 4:8; 11:17 en 16:5. In die Joodse uitlegtradisie is daar soortgelyke omskrywings wat op hulle beurt as uitleg van Eksodus 3:14 diens doen, wat daarop dui dat die Godspredikaat in bogenoemde verse in Openbaring 'n uitbouing van die Godsnaam in Eksodus 3:14 kan wees: 'Ek is wat Ek is' (vgl Büchsel 1964:399; Weiss 1991:715). In Openbaring word soms die formules 'die Alfa en die Omega' en 'die Eerste en die Laaste' by die Godspredikaat gevoeg (Op 1:8; 21:6: 22:13). Die interessante is verder dat in Openbaring 1:17; 2:8; 22:13 hierdie byvoegings ook op Christus van toepassing gemaak word. Dit laat vermoed dat die formule 'gister, vandag en tot in ewigheid' in Hebreërs 13:8 as Christologiese uitbreiding van die Godspredikaat 'wat was, wat is en wat kom' verstaan kan word (so Weiss 1991:715). Maar dan moet ons aanvaar dat dit nie die bedoeling van die Hebreërskrywer is om hier 'n algemene uitspraak oor Jesus se Godheid, of sy status as 
gelyk aan JHWH of as wêreldheerser te maak nie. ${ }^{15}$ Dit gaan hier oor Jesus se ewigheid, die feit dat Hy altyd dieselfde (ó $\alpha$ v่tós) is; kortom, dit handel oor die onveranderlikheid van die openbaring in Christus, en om dit as grond vir die paranese in vers 7 aan te wend dat die gemeente getrou moet bly aan die leer en geloof van hulle leiers (Attridge 1989:393; Michel 1966:491; Weiss 1991:716).

Die feit dat die belydenis in Hebreërs 13:8 op 'n unieke manier geformuleer is (gister, vandag en tot in ewigheid) en nie die gewone patroon van die Godspredikaat (wat was, wat is en wat kom) volg nie, dui volgens sommige geleerdes ook op die unieke heilshistoriese werk van Christus. 'Gister' is nie gelyk aan 'van alle ewigheid af' nie. Christus is wel van alle ewigheid af die Seun (Heb 1:1-14, veral v. 8-12), maar Hy het eers 'gister' Hoëpriester geword. Deur lyding het Hy geleer wat gehoorsaamheid is (5:8-10). So gesien, is vers 8 in der waarheid 'n kompakte samevatting van die hele voorafgaande twaalf hoofstukke van Hebreërs (so Filson 1967:34). 'Gister' kan egter ook op die onlangse verlede van die gemeente dui toe hulle deur die leiers in die evangelie onderrig is. Lane (1991:529) verkies hierdie moontlikheid vanweë die noue verbintenis tussen vers 8 en vers 7. Jesus Christus bly daarom 'vandag' ook die objek van die gemeente se geloof, ${ }^{16}$ en sal dit 'tot in ewigheid' bly omdat 'ewigheid' juis een van die kenmerke van die redding is wat Jesus as ewige Hoëpriester verwerf het - vgl. 5:9; 7:24-25; 9:12, 14-15; 13:20 (Lane 1991:530). Dit is sekerlik moontlik om bogenoemde afleidings te mak uit die wyse waarop die belydenis omtrent Christus in 13:8 geformuleer is. Maar wat in elk geval bo alle twyfel staan, is dat die klem duidelik op die onveranderlikheid van Christus val - dat Hy altyd dieselfde is (Attridge 1989:393). Dít is die aspek waarby die skrywer aansluiting vind wanneer hy vers 8 in sy onmiddellike konteks aanwend. En dit bring ons by die eerste element van vers 8 se funksie in Hebreërs 13, naamlik sy skakeling met vers 7 as begronding van die leiers se leer en lewe.

\section{Bevestiging en begronding van die leiers se leer en lewe (Heb 13:7-8)}

Die voor die hand liggende verbinding van vers 8 is met vers 7. In vers 7 word die gemeente soos volg opgeroep:

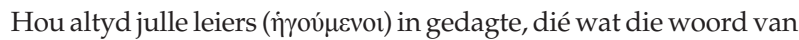
God aan julle verkondig het; deur ag te slaan op die uiteinde van hulle lewensloop, neem hulle geloof as voorbeeld (eie vertaling). ${ }^{17}$

15.In Barth se hantering van hierdie vers (kyk Hunsinger 2012:119-124) is dit juis Jesus se unieke verhouding met God waarop die fokus val. Barth gee min aandag aan die kontekstuele funksie van Hebreërs 13:8, maar bring hierdie vers in verband met die drie vorme van Christus se parousie - verlede: sy koms in lyding; toekoms: sy koms in heerlikheid waar alles herstel word; hede: sy intermediêre koms wat sekondêr bou op sy eerste koms, maar terselfdertyd die finale herstel van alles en almal antisipeer. Verder bring Barth hierdie interpretasie van Hebreërs 13:8 ook in verband met die Triniteit. Net soos die drie Persone in die Drie-eenheid mekaa onderling 'deurdring' (die perichoresis-gedagte), so deurdring Christus as God ook die drie vorme van sy parousie. Hierdie vorme is die ewige God se een handeling in Jesus Christus.

16.Dit word soms gesê dat Jesus in Hebreërs nie die objek van geloof is nie, maar eerder die volmaakte voorbeeld daarvan. Maar die Christologiese formule in 13:8 en sy skakeling met vers 7 as begronding van die inhoud van die leiers se geloof toon duidelik dat Christus ook die objek van geloof is (Lane 1991:528).

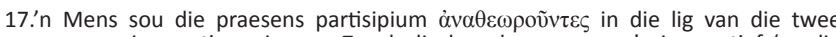
praesens imperatiewe in vers 7 ook die krag kon gee van ' $n$ imperatief (so die


wydverbreide term in die antieke vir leiersfigure van hoë aansien - sekulêr of religieus - maar word nie inhoudelik gevul nie. Die presiese status of amp wat sulke leiers beklee, moet uit die konteks afgelei word. Elders in die Nuwe Testament word die term ook gebruik vir (Christelike) leiers (Judas Barsabas en Silas - Hand 15:22; leier - Luk 22:26). Ook hier is hulle baie algemene leierskapsterme (Lane 1991:526). Dat die leiers in Hebreërs 13 wel 'n onderskeidende amp beklee het in die gemeente aan wie Hebreërs gerig is, kan afgelei word uit die volgende: die onderskeid wat daar getref word tussen die leiers en 'die heiliges' (gemeente) (v. 24) (Weiss 1991:710), dat hulle die Woord van God aan die gemeente verkondig het, en dat hulle lewe as voorbeeld dien vir die gemeente (v. 7). Verder beklee hulle ook 'n pastorale funksie (v. 17: waak oor die siele van die gemeente), en hulle moet rekenskap van hulle werk aan God gee (v. 17). Die gepaste optrede van die gemeente teenoor die leiers is gevolglik dié van gehoorsaamheid (v. 17): om die leiers se lewenswandel as voorbeeld te neem en hulle geloof na te volg (v. 7) (Grässer 1992a:216). Die amp wat die leiers beklee, het egter nie 'n hiërargiese konnotasie in die sin van die Frühkatholizismus nie, omdat die amp aan 'n funksie gekoppel word, naamlik die verkondiging van die Woord. Die leiers is dus ondergeskik aan die Woord (v. 7) (Weiss 1991:710-712). Ook in hulle pastorale funksie is hulle aan hoër gesag onderworpe, want hulle moet aan God rekenskap van hierdie werk gee (v. 17). Grässer (1992a:223) is gevolglik van mening die rede vir die gebruik van so 'n 'profane' term


is omdat hierdie amp aan Christus gekoppel is. Christus is die eenmalige Hoëpriester. Die 'profanisering' van die amp word gedoen ter wille van die heiligheid van die boodskap (Grässer 1992a:226). Nie die boodskapper nie, maar die Boodskap verseker die waarheid. En agter hierdie Boodskap staan die gesag van Christus.

Dit is op hierdie punt dat die verhouding tussen vers 7 en vers 8 sigbaar word. Vanuit die beredenering in die vorige paragraaf vloei vers 8 nou logies voort om die gesag van die leiers te bevestig en te waarborg - nie soseer die persoon van die leiers nie, maar hulle funksie as verkondigers van die Woord. Jesus as die ewige en onveranderlike staan borg vir die kontinuïteit van die geloofstradisie wat deur die kerklike leiers in die verlede oorgedra is en wat hulle nog steeds doen. In die mate dat aardse leiers aan Christus getrou bly, in daardie mate word hulle werk en voorbeeld deel van die Christologiese basis van die gemeente wat tot in ewigheid stand hou (Attridge 1989:393). So gesien, neem die leiers ook hulle plek in die galery van Ou-Testamentiese geloofshelde in wat in Hebreërs 11 beskryf word (DeSilva 2000:494; Lane 1991:527). Die Christelike leiers is dus nie net draers van die outentieke apostoliese tradisie nie, maar hulle sluit aan by die geloofstradisie van die ou verbond. En agter hierdie tradisies staan die Seun as die ewige. Dat vers 8 dus

(Voetnota 17 vervolg ...)

meste vertalings). So gesien is daar dan drie selfstandige imperatiewe: hou in gedagte; slaan ag op; neem as voorbeeld. Dit is $\mathrm{m}$ i egter natuurliker om die partisipium as motivering by die laaste imperatief ( $\mu \mu \varepsilon i \tilde{\sigma} \sigma \varepsilon$, neem as voorbeeld) te neem (so Attridge 1989:390). 
as begronding of bevestiging van die leiers se Woordfunksie in die gemeente gesien word, vind ek die mees bevredigende omskrywing van vers 8 se funksie ten opsigte van vers 7 . Uiteraard moet verse 17-19, wat saam met vers 7 'n inclusio vir verse 7-19 vorm, ook betrek word. Die formule van vers 8 bevestig nie net die Woordfunksie van die leiers nie, maar begrond al hulle amptelike optredes, ook hulle pastorale funksie in die gemeente. Dít is ten diepste die rede waarom die leiers in herinnering geroep, gevolg en gehoorsaam moet word - omdat dit volgens vers 8 in navolging van en gehoorsaamheid aan Christus is.

Hoewel die bevestigende aard van vers 8 as sy hooffunksie ten opsigte van vers 7 aanvaar moet word, vervul dit ook 'n kontrasterende funksie. Michel (1966:490) en Bruce (1964:395) wys daarop dat vers 8 ook die ewigheid van Christus teenoor die tydelikheid van die aardse leiers (v. 7) benadruk. In laasgenoemde vers word byvoorbeeld op die $̌ \kappa \kappa \beta \alpha \sigma \iota \varsigma$ (uiteinde) van die leiers gewys. Dit verwys waarskynlik na hulle dood (Attridge 1989:392) sonder om daaraan 'n martelaarseinde te koppel, hoewel dit nie totaal uitgesluit is nie in die lig van 10:32-34 se verwysing na die gemeente se vorige lyding (Bruce 1964:395; Michel 1966:490). Die ewigheid van Christus se hoëpriesterskap teenoor die tydelikheid van die aardse priesters kan ook hier betrek word (7:22-24). Die punt is: tot by die einde van hulle lewe het die leiers in die regte leer en met 'n voorbeeldige en navolgenswaardige lewe volhard. Maar dit het tot ' $n$ einde gekom, soos die lewe van alle aardse leiers, hoe voortreflik ook al. Al wat werklik stabiliteit gee, is die ewigheid van Christus. Net Hy alleen bly vir altyd, net Hy is ó av̉ós. Hy is die enigste blywende oriëntasiepunt te midde van die vloei van die gewone lewe (Woschitz 2000:81).

Soms word ook die moontlikheid gestel dat daar 'n leierskapstryd in die gemeente was, en dat die klem in vers 8 op die ewigheid van Christus subtiel hierteen gemik is. Maar hierdie interpretasie gaan mank aan enige aanduidings in die teks van Hebreërs wat verwysings na so 'n leierskapkrisis bevat. Verder verbreek so ' $n$ interpretasie ook die noue band tussen vers 8 en vers 7 . In vers 7 is geen aanduiding van 'n leierskapstryd nie; inteendeel, die gemeente word juis opgeroep om die leiers se voorbeeld te volg, en in vers 17 om aan hulle onderdanig te wees (Lane 1991:528).

Dit bly dus die beste moontlikheid om vers 8 se funksie as dié van begronding of bevestiging van die werk van die leiers in vers 7 (en v. 17) te sien. Dit is ook meer in pas met die verdere rol wat vers 8 in Hebreërs 13 speel, soos verder beredeneer sal word. Die leer en lewe van die leiers word naamlik ondersteun en teologies begrond deur die persoon en werk van Jesus Christus self.

\section{Kontrastering: Bestry dwalinge (13:8-9)}

Waar vers 8 'n positiewe en bevestigende rol ten opsigte van vers 7 vervul, dien dit ten opsigte van vers 9, wat inhoud betref, weer as motivering tot weerlegging en afwysing van die dwalinge wat hier ter sprake is. Op formele vlak het vers 8 dus 'n kontrasterende funksie ten opsigte van vers 9 (Attridge 1989:393). Verder kan 'n mens sê dat die kwessie van dwalinge wat in vers 9 aan die bod kom, ook te make het met die argumentslyn van leierskap wat vroeër geïdentifiseer is. Want in die mate dat dwalinge die ronde doen, word die outentieke leer en voorbeeld van die leiers waarvan in vers 7 sprake is, uitgedaag en in gevaar gestel (so Lane 1991:530-531). Dus word die gemeente enersyds opgeroep om die leiers se leer en lewe na te volg (v. 7), en andersyds word hulle gewaarsku om nie deur allerlei vreemde leringe meegevoer te raak nie (v. 9). En tussenin staan v. 8 wat Jesus Christus as die onveranderlike waarheid van God voorhou.

As ons sê dat vers 8 'n kontrasterende funksie teenoor vers 9 het, word uiteraard die hele argument van verse 9-14 hierby betrek. Toe die argumentslyn van leierskap in 'n vorige afdeling bespreek is, is daarop gewys dat verse 9-14 die unieke posisie van Jesus, wat reeds in vers 8 gestel word, verder uitbou deur die onveranderlike genoegsaamheid van Jesus se persoon en werk te beredeneer. Daar is vroeër ook reeds genoem dat geleerdes hierdie verse as van die moeilikste in die Nuwe Testament beskou. Dit is dus nie die bedoeling om hier ' $n$ volledige uitleg van al die betekenismoontlikhede van verse 9-14 aan te bied nie, maar slegs 'n oorhoofse standpunt te stel wat die hoofstroom eksegetiese denke verteenwoordig sodat die funksie van vers 8 daarmee belyn kan word.

Wat presies die aard van die 'allerhande vreemde leringe' (v. 9) is wat'n suigkrag op die gemeente uitgeoefen het, is nie sonder meer duideliknie. Maar dit het na alle waarskynlikheid te make met Joodse voorskrifte rondom eetgebruike en

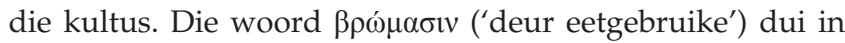
hierdie rigting (Attridge 1989:394; Lane 1991:534-535; Young 2002:247). Veral die opmerking dat dit dié wat daarvolgens lewe, niks baat nie, asook dat dit teenoor 'genade' ( $\chi \alpha$ ó gestel word wat die eintlike rus in die gemoed bring, bevestig hierdie vermoede. Want genade gaan hier oor die genade wat deur die versoeningswerk van Christus tot stand gebring is (Lane 1991:535; Michel 1966:496-497; Weiss 1991:719). Maar hoekom word dit vreemde leringe genoem as dit juis vertroude opvattings vanuit 'n Joodse konteks was wat 'n suigkrag op die lesers kon uitoefen? Attridge (1989:393) wys daarop dat die uitdrukking 'vreemde leringe' dikwels in waarskuwings teen kettery voorkom sonder dat daarmee noodwendig iets eksoties, soos die sakramentele praktyke van Gnostiese groepe, bedoel word. Verder, indien die dwaling van 'n vreemde, afstootlike aard was, sou die skrywer waarskynlik baie hewiger daarteen gereageer het (Filson 1967:52; Lane 1991:532). Maar nou is dit juis vanweë die bekendheid daarvan gevaarlik. Die uitdrukking 'allerhande en vreemde' kan ook dui op die verskeie en vreemde rondreisende leraars wat die lesers se harte verwar. Dit word dan gestel teenoor die bekendheid van hulle gestorwe leiers en Jesus Christus self wat altyd dieselfde is (Lane 1991:532). Dus, wat ook al die spesifieke aard van die dwalinge was, vir die Hebreërskrywer was dit iets wat presies die teenoorgestelde was van die lewe 
binne die nuwe verbond in Christus, en daarom 'vreemd' (Attridge 1989:396).

Verder kan die 'vreemde leringe' en 'eetgebruike' as metaforiese spreekwyse gesien word vir die totale ou manier van aanbidding waarin die Judaïsme van die tyd vasgevang was (so Young 2002:247-248, 254-255; vgl. DeSilva 2000:496). Op een lyn hiermee kan die moeilike vers 10 dan verstaan word as 'n verdere poging om die lesers te oortuig dat die

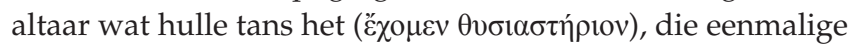
offerande van Christus aan die kruis is (so Attridge 1989:396; Koester 1962:313-314; Lane 1991:537-538; Walker 1994:41; Young 2002:248). ${ }^{18}$ Die skrywer sit dus in vers 10 die kultiese taalgebruik voort waarmee in vers 9 begin is en wend dit metafories aan om die heil wat nou in Christus beskikbaar is, te beskryf. Ou-Testamentiese kategorieë word naamlik gebruik om wat die heel belangrikste van Christus se offerande is, te beklemtoon (Attridge 1989:397). Hughes (1977:577) sê daarom dat 'altaar' 'n soort snelskrif of sinekdogee is vir die totale offerhandeling van Christus. Hierdie offerande is voldoende om die verhouding met God te vestig en in stand te hou.

Die frase 'waarvan dié wat in die tent/tabernakel diens verrig, nie mag eet nie' (v. 10), kan op sy beurt as 'n voortsetting van $\beta \rho \omega ́ \mu \alpha \sigma ı$ se verwysing in vers 9 verstaan word (Attridge 1989:397). Hoewel dit streng gesproke na die Levitiese dienswerk in die tabernakel verwys, verwys dit ook na '... anyone whose worship is still conditioned by the system of the Levitical law. This is a negative description of Judaism ...' (Young 2002:247). Hierdie frase dui dus eweneens op Joodse of Joods-Christelike tradisies wat bly voortbestaan het ten spyte daarvan dat dit in Christus reeds getermineer is (Attridge 1989:394). ${ }^{19}$

In verse 11-12 word die unieke offer van Christus verder verduidelik as iets wat teenoor die offerkultus van die ou verbond staan, soos reeds voorheen in Hebreërs verduidelik $($ Heb 7,9$)$. Die belangrike punt hier is dat Jesus sy offer buite die laer gebring het. Anders as die hoëpriester van die ou verbond wat die reiniging van die volk se sonde binne die laer bewerk het met die bloed van diere, doen Jesus dit met sy eie bloed en buite die laer, daar waar tradisioneel die liggame van die offerdiere verbrand is en waar dit gevolglik

18.Daar was in die verlede pogings om 'altaar' met die Christelike kultus van die nagmaal in verband te bring, maar dit kan nouliks vanuit die teks gehandhaaf nagmaal in verband te bring, maar dit kan nouliks vanuit die teks gehandhaa word. 'Altaar' is eintlik net ' $n$ inleiding tot verse 12-14 waar 'altaar' verduidelik word as die offerdood van Christus. Verder moet die term in verband gebring word met die vroeë kerk se manier om op simboliese manier uitdrukking te gee aan die kompleksiteit van Christus se offerdood, soos dit veral in Hebreërs verduidelik

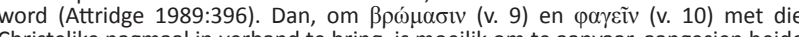
Christelike nagmaal in verband te bring, is moeilik om te aanvaar, aangesien beide in die konteks van Hebreërs as behorende tot die ou (en agterhaalde) kultiese orde gesien word (Weiss 1991:725). Laastens: die skrywer kan beswaarlik in verse 9 die genade teenoor allerlei kultiese eetgebruike stel, en dan in verse 10 in dieselfde asem na'n kultiese maal verwys (Lane 1991:538)

19. Braun (1984:463-464) slaan ' $n$ eie weg in met die interpretasie van die frase: 'waarvan dié wat in die tent/tabernakel diens verrig, nie mag eet nie' (v. 10). Teenoor die meeste geleerdes wat hierdie frase as ' $n$ verwysing na navolgers van Joodse tradisies beskou, interpreteer Braun dit as 'n verwysing na Christene. van Joodse tradisies beskou, interpreteer Braun dit as ' $n$ verwysing na Christene. verhouding met God kan bevestig nie (bv. deur die nagmaal), maar hulle moet Christus op ' $n$ nie-sakrale manier volg, soos dit in verse 13-14 verduidelik word. Hoewel nie onmoontlik nie, is daar net te veel formulerings in verse 10-12 wat hierdie interpretasie bemoeilik, soos die meeste geleerdes met hulle uitleg van hierdie verse aantoon. onrein was. Die skrywer is net in een saak geïnteresseerd, en dit is om met gebruikmaking van die ou verbond se kultiese taal twee alternatiewe en onderling uitsluitende versoeningsgebeure teenoor mekaar te stel - dié van die ou verbond wat uitgedien is, en dié van die nuwe verbond in Christus wat die oue vervang.

Die oproep word gevolglik gedoen (vv. 13-14) dat die gelowiges die vertroude en veilige heiligdom, wat klaarblyklik nog 'n suigkrag uitgeoefen het (v. 9!), moet agterlaat en na Christus uitgaan, om sy smaad te dra en so hulle plek in te neem saam met die vader van die gelowiges, Abraham, wat die toekomstige stad van God verwag het (11:10), soos ook die ander gelowiges wat ná hom gekom het $(11: 14,16,40)$. Die heiligdom is nou nie meer binne die bestaande sisteem wat tot hiertoe 'n veilige godsdienstige vesting gebied het nie, maar buite die sisteem waar Christus is. Hy is die nuwe heiligdom, deur Hom moet God aanbid word. Die sakrale moet verruil word vir die nie-sakrale, die nuwe ruimte van aanbidding wat gister, vandag en tot in ewigheid dieselfde is. Die ou wankelrige sisteem is vervang met die onwankelbare.

Bostaande is voldoende om die funksie van vers 8 te verstaan in sy verbinding met vers $9(-14)$. Die funksie van vers 8 is naamlik om Christus as die enigste en blywende waarheid te stel en so dwalinge te bestry. Om saam te vat: Teenoor die veelvoud van vreemde leringe (v. 9) kan en moet die lesers aan Christus vashou as die één en vertroude waarheid wat sedert die ontstaan van die gemeente deur die leiers aan hulle voorgehou is. Daaraan het nog niks verander nie, en dit sal tot in ewigheid ook nie. Christus is dieselfde, die onveranderlike. En dan vervolg die skrywer om hierdie unieke posisie van Christus kortliks te verduidelik in verse 10-14 deur nogeens op die kontras tussen die ou verbond en die nuwe verbond in Christus te wys - die unieke, finale manier waarop Hy sy volk geheilig het (wat in wese niks anders is nie as waarmee die skrywer in sy hele geskrif besig was). En laastens roep hy die gemeente finaal op om hulle pelgrimstatus te aanvaar en Christus te volg waar dit saak maak - buite die laer. Dit bring ons by die derde element van 13:8 se funksie in Hebreërs 13.

\section{Stabiliteit op die pelgrimsreis (Heb 13:8, 13-14)}

Soos in 'n vorige afdeling beredeneer, vorm Hebreërs 13:9-14 'n geïntegreerde argument. Dit is egter ook so dat daar met die oproep in vers 13 , en sy motivering in vers 14 , 'n nuwe moment in die argument na vore tree, naamlik om uit te gaan na Jesus buite die laer $(\pi \alpha \rho \varepsilon \mu \beta 0 \lambda \eta ́)$ en sy smaad te verduur (13), omdat ons hier nie 'n blywende stad het nie, maar op soek is na die toekomstige (14). Dat die oproep om uit te gaan na Jesus reeds in verse 11-12 voorberei is (lg. die teologiese motivering by v. 10) is ewe duidelik, want in vers 11 word genoem dat die liggame van die offerdiere 'buite die laer' verbrand is, en in vers 12 dat Jesus 'buite die hek' gely het.

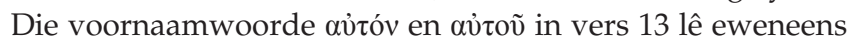
die verband met Jesus in vers 12 . So gesien, skakel die oproep vervat in verse 13-14 uiteindelik ook met vers 8 (die fokus 
van hierdie studie), aangesien, soos reeds beredeneer, verse 10-12 niks anders is nie as 'n verdere uitleg van vers 8 . In hierdie afdeling wil ons met name aantoon dat vers 8 nie net ' $n$ rol te speel het in sy onmiddellike tekstuele omgewing nie (vv. 7,9), maar ook in die verdere argument. Dit is juis die leemte in die navorsing dat vers 8 nie overt met die argument tot ten minste in vers 19 in verband gebring word nie. Die betoog in hierdie afdeling is dus dat vers 8 'n funksie vervul in die argumentslyn van die pelgrimsmotief in Hebreërs 13.

Dat die pelgrimsmotief sterk in Hebreërs figureer, en in Hebreërs 13 sy afsluiting vind, spesifiek in 13:13-14, is reeds vroeër betoog. Wat presies bedoel word met die oproep om uit te gaan na Jesus buite die laer, word nie deur alle navorsers dieselfde geïnterpreteer nie. Sommige is spesifiek daaroor dat die lesers opgeroep word om die Judaïsme finaal agter te laat ter wille van hulle nuwe identiteit in Christus (so Lane 1991:546; Walker 1994:42, 44; Young 2002:255-256). Vir Attridge (1989:399) gaan dit egter nie soseer oor die Jodedom nie, maar daaroor dat die skrywer eerder die beeld van die kamp of laer kreatief-uitlokkend aanwend. Met 'laer' wil die skrywer naamlik die terrein van tradisionele sekuriteit en heiligheid voorstel, maak nie saak in watter spesifieke agtergrond dit gegrond word nie. Dit is egter moeilik om te aanvaar dat die Hebreërskrywer nie 'n spesifieke agtergrond - dié van die Jode - in gedagte gehad


9) nie. Die hele trant van die argument in Hebreërs 13 dui daarop dat hy met 'n spesifieke sosiaal-kulturele klankbord werk. Daarmee beweer ek nie dat Hebreërs primêr 'n polemiese geskrif, gerig teen die Jodedom, is nie. Dit is eerder 'n pastoraal-paranetiese geskrif wat sy lesers uitdaag om te volhard, synde mense wat deel is van die nuwe verbond in Christus (vgl. Lane 1991:536). ${ }^{20}$ Uiteraard kan die spesifieke agtergrond waarmee Hebreërs werk, ook as simbool vir wyer toepassing ontgin word, maar die leefwêreld van die eerste lesers kan nie geïgnoreer word nie.

Waarin bestaan die 'uitbeweeg na Jesus toe' dan nou? In die algemeen het dit met die pelgrimstema te doen, maar dié kan inhoudelik met minstens twee motiewe geassosieer word. Die eerste is dat die pelgrims die smaad (ỏveı $\delta \_\mu \mu$ ć) van Jesus buite die laer of hek/stadspoort vrywillig hulle eie moet maak en dra (v. 13). Vers 13 is kennelik 'n verwysing na Levitikus 16:27. Vanuit hierdie konteks simboliseer 'buite die laer' veral onreinheid. Volgens die voorstelling in Levitikus is die area buite die laer onrein (dis waar die liggame van die offerdiere verbrand word), terwyl die bloed deur die hoëpriester binne die laer, in die sakrale gedeelte, die Allerheiligste, ter versoening van die volk se sonde ingedra word (vgl. ook 13:11). Wat Jesus se lyding buite die laer betref, lê die klem weer veral op sy vernedering. Hy ondergaan vernedering, spot, hoon, lyding en dood buite die stadspoort van Jerusalem, in die nie-sakrale ruimte. Maar so word dáár juis 'n nuwe heiligdom of altaar opgerig. En as

20.Selfs Young $(2002: 258-260)$, wat daarvan oortuig is dat die toonaard van die kontraste in Hebreërs baie polemies van aard is, erken dat die geskrif eerder ' appèl tot die lesers rig om hulleself af te grens van die sterker en meer sosiaal jy met Christus wil identifiseer, is dit buite die stad waar jy Hom moet ontmoet en volg. Tereg wys navorsers (vgl. Isaacs 1997:282; Lane 1991:543) daarop dat hierdie uitbeweeg na Jesus toe Hebreërs se bekendheid met die vroeg-Christelike tradisie van die imitatio Christi illustreer - die oproep om Jesus se kruis op te neem en Hom te volg, soos dit voorkom in die Sinoptici. Die veilige ruimte binne die laer is nie meer die plek om Hom te dien nie, maar wel in die wêreld - dáár moet die lyding van Christus gedra word.

Die tweede assosiasie met die pelgrimsmotief is die feit dat pelgrims nie meer 'n blywende stad op aarde het nie, maar op soek is na die stad wat nog kom (v. 14). Navorsers soos Grässer (1992c:251-264), Johnson (2001:68-69) en DeSilva (1995:208) laat vanuit sosiologiese ondersoeke die lig val op die betekenis van die antieke $\pi$ ó $\lambda$ ı - dat dit nie net 'n toevallige woonplek was nie, maar aan sy burgers status en identiteit verleen het. Sonder hierdie identiteit was jy 'n ontheemde, 'n vreemdeling, en nêrens tuis nie. En dit is presies wat van die lesers van Hebreërs gesê word, dat hulle ontheemdes is, met geen vaste $\pi$ ó $\lambda$ ı op aarde nie, maar op soek na die Godstad wat nog kom. Hulle ware identiteit vind hulle nie in wat hier $(\tilde{\omega} \delta \varepsilon, \mathrm{v} .14)$ en tydelik is nie, maar in wat ewig is, wat God vir hulle in die vooruitsig stel en wat hulle voorlopig reeds in Christus ervaar. Op hierdie manier word die lesers by die geloofshelde van die Ou Testament ingeskakel, van wie ook gesê word dat hulle hier geen vaste woonplek gehad het nie omdat hulle na die Godstad, die hemelse vaderland (11:10, $14,16,40)$ op soek was. ${ }^{21}$

Dit is in hierdie verband dat 13:8 'n belangrike funksie in die argument vervul. Attridge (1989:399) noem dat die lesers in

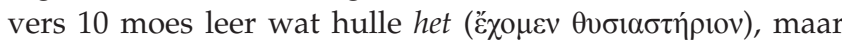

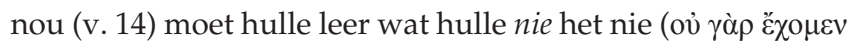

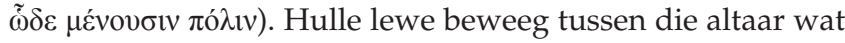
hulle het (die offer van Jesus Christus) en die uiteindelike bestemming wat nog nie finaal gerealiseer het nie. ${ }^{22}$ Maar presies dít is die belangrike: in hulle pelgrimsreis na die Godstad is hulle nie doellose en ankerlose swerwers nie; hulle het ' $n$ 'anker van die siel' in Jesus Christus, Hy wat reeds aan die binnekant van die tempelgordyn ingegaan het (6:19), die Voorloper en Hoëpriester (6:20), die Leidsman en Voleinder van die geloof wat voortdurend in die oog gehou moet word (12:2), die Een wat gister, vandag en tot in ewigheid dieselfde is (13:8). Die teruggrype van 13:13-14 na vers 10 en vers 8 bied hierdie stabiliteit op die pelgrimstog. Vers 8 bly so die teologiese ruggraat van Hebreërs 13. Dit mag wel wees dat die beeldspraak ietwat geskuif het van om 'in te gaan' in die rus wat Christus bewerk het (4:11), of 21.Johnson (2001:75-81) doen 'n sosiologiese analise van die geimpliseerde lesers
van Hebreërs en tipeer hulle as 'n 'boundary crossing' gemeenskap met poreuse van Hebreërs en tipeer hulle as ' $n$ 'boundary crossing' gemeenskap met poreuse grense wat potensieel oop is vir buitestanders. Sosiologies gesproke is hierdie nie, maar oorgesteek. Desilva (1995:208) noem ook dat die gelowiges in Hebreërs nie heropname (re-enfranchisement) in die Grieks-Romeinse samelewing moet soek nie, maar as 'n gemeenskap van gelowiges moet voortgaan wat Christus volg en hulle eie lewenstyl het (bv. 13:1-6)

22.Walker (1994:42-43) noem dat die tempel vroeër in Hebreërs vertikaal aangewend is (tempel is' $n$ tipe van Christus se ingaan in die allerheiligste, die hemel). In 13:13 word die tempel egter horisontaal aangewend - die heiligdom is nou buite die laer. Wie Christus wil dien, moet Hom buite die kamp dien. Saunders (1979:23-24) sien Wie Christus wil dien, moet Hom buite die kamp dien. Saunders (1979:23-24) sien
die hele Hebreërs 13 as die inhoud van wat dit beteken om ' $n$ outside lewenstyl te hê. 
om 'nader te gaan' na die troon van genade (4:16; 10:22), na een van om 'uit te gaan' (die 'teenoorgestelde' rigting), maar die doel van die beweging is dieselfde: om 'na Hom' ( $\pi \rho$ ò $\varsigma$

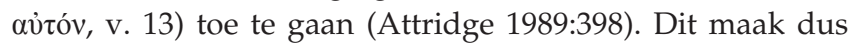
nie saak dat die pelgrimstog ook 'n kruistog word met al die ontberings, aanvegting en lyding wat dit meebring nie, want daar is stabiliteit vanuit die geloof in die Een wat ewig is. Dis wel 'n uitwaartse beweging, maar vanuit die vaste oortuiging dat dit in navolging van Hom is wat gister, vandag en tot in ewigheid dieselfde is.

Hierdie vashou aan Jesus wat altyd dieselfde is, het egter niks te make met 'n starre, droë ortodoksie nie; nee, dis dinamies en vol beweging. Daar is voortdurende beweging vanweë die uitdagings wat die lewe en die aard van dissipelskap inhou. Die heiligdom is nie meer binne die kamp, binne gevestigde sisteme nie, maar buite in die wêreld waar daar gevare en lyding is. Maar hierdie beweging is te onderskei van een wat ongetoets, sonder oriëntasie, koers of rigting is (Hegermann 1988:273). Daarom is Isaacs (1997:282-283) reg as sy Koester (1962:302) se standpunt afwys wat sê dat die uitbeweeg na buite die kamp 'n oproep is dat die kerk sy sekulêre taak in die wêreld moet opneem. Dit sou 'n vreemde konsep vir die antieke kerk gewees het. Dis wel waar dat die kerk nie in escapism mag verval nie, maar Hebreërs se oproep om buite die kamp uit te beweeg is eerder 'n herlokalisering van die sakrale - nie in die Judaïsme nie, maar in die hemel waarheen die pelgrimerende gemeenskap op pad is (vgl. ook DeSilva 2000:501). Dis juis vanuit die altaar wat hulle in Christus het (v. 10), wat op sy beurt 'n uitleg is van wat met vers 8 se belydenisuitspraak bedoel word, dat hulle vanuit ' $n$ nuwe maar stabiele aanbiddingsfokus op weg is na die stad waarvan God die grondlegger is (11:10; 13:14).

\section{Christologiese basis vir God welgevallige offers (Heb 13:8, 15-16)}

Die vierde en laaste element van die funksie van vers 8 in Hebreërs 13 het te make met die argumentslyn van ware aanbidding. Hoewel hierdie trajek in die hele Hebreërs 13 voorkom, soos reeds in 'n vorige afdeling beredeneer, gaan dit nou veral oor verse 15-16 en die skakeling van hierdie verse met vers 8 . In verse 15-16 gaan dit oor die offers waardeur God behaag word ( elemente: om God voortdurend te loof, om goed te doen en om mededeelsaam te wees. Die bewoording is sodanig dat die Ou-Testamentiese gebruike en opvattings rakende die offerkultus duidelik waarneembaar is: $\alpha v \alpha \varphi \varepsilon ́ \rho \omega \mu \varepsilon v$

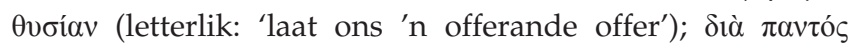

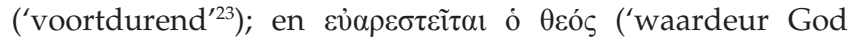
behaag word' / 'wat vir God aanneemlik is'). Klaarblyklik wil die outeur doelbewus die verband met verse 10-13 lê waar Christus se versoeningswerk teen die agtergrond van die Ou-Testamentiese offerkultus beskryf word. Maar terselfdertyd slaan Hebreërs met hierdie werkwyse ook die brug na wat hy eintlik bedoel. Wedderburn (2005:409-410)

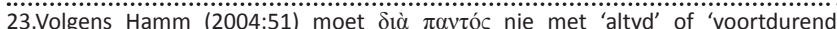
vertaal word nie, maar eerder met 'gereeld' of 'reëlmatig', omdat dit na die Ouvertaal word nie, maar eerder met 'gereeld' of 'reëlmatig', omdat dit na die Ou-
Testamentiese tamid-offers verwys wat op gereelde tye in die tempel geoffer is



maak ons daarop attent dat Hebreërs soms soos iemand is wat die tak afsaag waarop hy sit. Hy doen moeite om 'n hele terminologiese konstruksie op te bou, spesifiek rondom die offerkultus, maar 'breek dit weer af' om die simboliek daarvan vry te stel. Dit is veral so in Hebreërs 13:15-16: Hebreërs gebruik offerterminologie, maar hy wil nie hê ons moet ons blind staar teen die terme self nie; wat hy eintlik wil sê, is dat ons heelhartig toegewy moet wees aan God en medemens. Hierdie vergeesteliking van die offers is deur navorsers ook vanuit sosiologiese hoek beoordeel. Johnson (2001:114) wys byvoorbeeld daarop dat dit tipies is van 'n 'swak' groep, sosiologies gesproke, om nie streng te hou by geykte rituele nie, maar met spontane optrede deur die grense te breek. In die geïmpliseerde gemeenskap van Hebreërs is dit duidelik dat die kultus vervang is met lofprysing, diens en onderlinge sorg, "activities more closely akin to "spontaneous expression" than to ritual sacraments' (Johnson 2001:114). En volgens DeSilva (1995:274) is die elemente van lofprysing tot God en diens aan die medemens weer ' $n$ aanduiding van die eerbetoon wat aan God as die Weldoener (Benefactor) en aan Christus as die Middelaar (Broker) van die gemeenskap bewys word vir al die weldade van redding wat die gemeenskap ontvang het. Deur aksies van wederkerige welwillendheid word die gemeenskap van gelowiges gebou en word God geëer, asook sy toorn afgewend (Heb 10:26-31). Egte godsdiens in die nuwe verbond kan dus weliswaar in terme van die ou verbond geformuleer word, maar die inhoud het sedert die koms van Christus 'n ander, ryker inhoud bekom - 'n inhoud meer in ooreenstemming met wat werklik vir God aanneemlik is. Juis die alledaagse lewe word sakraal gemaak wanneer God en Christus openlik bely en die mede-Christen gehelp word (DeSilva 2000:507).

Dit is verder opmerklik dat hierdie argumentslyn van ware aanbidding, soos uitgedruk in verse 15-16, ook met vers 8 verbind kan word. Ten einde hierdie verbinding te bepaal speel $\delta \imath^{\prime} \alpha$ ơ $\tau$ ov in vers 15 'n deurslaggewende rol. Nie net staan hierdie woorde in 'n prominente posisie aan die begin van die sin nie, maar dit is ook duidelik dat hulle die koppeling met die voorafgaande argument bewerkstellig. Braun (1984:469-470) wys daarop dat hierdie formule na Jesus as die Middelaar van die lofoffer verwys; Hy is ó av่ ós, en dié wat God loof, moet na Jesus uitgaan en sy smaad dra (v. 13). Lane (1991:548) merk ook op dat daar 'n merkwaardige ooreenstemming

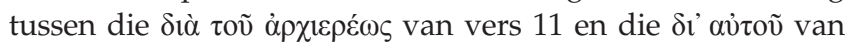
vers 15 bestaan (vgl. ook Weiss 1991:738). In die ou verbond is dit die hoëpriester wat die middelaarsrol vervul waardeur die offers aan God gebring word. In die nuwe verbond is dit Jesus wat hierdie middelaarsrol vervul. ${ }^{24}$ Die groot verskil is verder die aard van die offers: dáár was dit diereoffers, nou is dit offers van lof, goeie dade en mededeelsaamheid, die eintlike offers wat vir God welgevallig is. Klauck (2006:434) is daarom van opinie dat verse $15-16$ as die uitleg van vers 13 kan dien: indien gevra word hoe die smaad van Jesus gedra moet word (v. 13), dan is lof, die doen van die goeie en mededeelsaamheid deel van die antwoord. Soos reeds

24.Volgens Lane (1991:548) beluister mens hierin selfs'n polemiese toon, gemik teen die rituele van die ou verbond en dié wat nog daarmee voortgaan of dit hoog ag. 
voorheen genoem, sluit dit ook aan by die oproep in 13:1-6 om broederliefde en gasvryheid uit te leef en die gevangenes te versorg. Dít is die ware aanbidding, die manier waarop God behaag word, selfs al hou dit spot, verguising en lyding in. Dit alles kan verder teruggevoer word na verse 8-9. Weiss (1991:738) wys daarop dat die $\delta \imath^{\prime} \alpha$ $\tau$ toṽ van vers 15 nie net op Jesus dui wat buite die laer gesterf het nie (v. 12), ${ }^{25}$ maar ook in verband staan met die genadegeskiedenis van vers 9 (dat

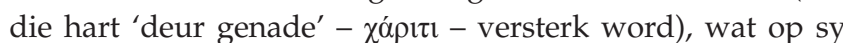
beurt gegrond is in Jesus Christus wat gister, vandag en tot in ewigheid dieselfde is. ${ }^{26}$ Volgens Weiss (1991:738-739) verkry die instrumentele $\delta$ ' $\alpha$ ỡoṽ só ook 'n kousale betekenis: dit is slegs deur Christus dat dit vir Christene moontlik word om offers te bring wat vir God welgevallig is. Die Christen se offer is daarom nie meer 'n soenoffer nie - dit het Christus klaar


voortvloei uit daardie offer wat alles moontlik gemaak het. Via sy verbinding met die hele argument van verse 9-16 vervul vers 8 dus ook die bykomende funksie om as Christologiese basis te dien vir die offers waarvan in verse $15-16$ sprake is (vgl. ook Hübner 1995:60). En dis presies die Christologiese basis wat die Christen se lofprysing van die vergelykbare Bybels-Joodse lofprysings ${ }^{27}$ onderskei (Weiss 1991:741).

\section{Slot}

In die lig van die voorafgaande uiteensetting kan die kontekstuele funksie van Hebreërs 13:8 soos volg saamgevat word. Hierdie enigmatiese, formuleagtige vers vorm die teologiese ruggraat van die argument tot ten minste Hebreërs 13:19. So gesien, vervul dit 'n vierledige funksie: eerstens, vanuit die verbinding met vers 7 dien dit as bevestiging en begronding van die geestelike leiers se leer en lewe; tweedens, vanuit die verbinding met vers $9(-14)$ het dit 'n kontrasterende funksie deurdat dit die dwalinge bestry wat in omloop is; derdens, vanuit die verbinding met verse 13-14 het dit die funksie om stabiliteit in die gemeente se pelgrimsreis na die Godstad te bied; en vierdens, vanuit die verbinding met verse $15-16$ vorm dit die Christologiese basis vir die gemeente se ware godsdiens van lof aan God en diens aan die medemens.

\section{Erkenning}

Hierdie artikel word met dankbare erkenning opgedra aan my jare lange kollega en vriend, Pieter de Villiers. Ons het vir lank saamgewerk in die aanbieding van die M-graad in Bybelse Spiritualiteit aan die Universiteit van die Vrystaat. Ek het die hoogste waardering en bewondering vir sy akademiese en persoonlike integriteit. Hy is ook 'n meester van taalgebruik (Afrikaans én Engels) en het 'n fyn aanvoeling vir die betekenismoontlikhede wat die struktuur

25. Michell (1966:522) is van opinie dat vers 15 nouer aansluit by vers 12 as by vers

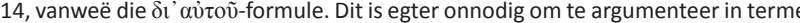
van nouer aansluiting of nie. Die hele argument vorm' ' $n$ verweefde eenheid. Dit is belangriker om die skakels in die argument te identifiseer.

26.Lane (1991:549) wys eweneens op die verband tussen vers 15 en die voorafgaande verse. Volgens hom kan mens dit terugwaarts soos volg voorstel: vers 13 - vers $12-11$ - vers 10

27.Vergelyk LXX Psalm 53:8; 98:3; 105:47; 121:4: 139:14 waar God ook geloof word as antwoord op sy goedheid en barmhartigheid. van die teks na vore bring. Dit is in die lig hiervan dat ek hierdie artikel, 'n eksplorasie van die konteks van Hebreërs 13:8, vir sy huldigingsbundel aanbied.

\section{Mededingende belange}

Die outeur verklaar hiermee dat hy geen finansiële of persoonlike verbintenis het met enige party wat hom nadelig of voordelig kon beïnloed het in die skryf van hierdie artikel nie.

\section{Literatuurverwysings}

Allen, D., 2008, 'Constructing "Janus-Faced" exhortations. The use of Old Testament narratives in Heb 13, 1-8', Biblica 89(3), 401-409.

Attridge, H.W., 1989, The Epistle to the Hebrews, Fortress, Philadelphia, PA. (Hermeneia.)

Braun, H., 1984, An die Hebräer, Mohr (Siebeck), Tübingen. (HandbuchzNT 14.)

Bruce, F.F., 1964, The Epistle to the Hebrews, Eerdmans, Grand Rapids, MI. (NICNT.)

Buchanan, G.W., 1972, To the Hebrews. A new translation with introduction and commentary, Doubleday, New York, NY. (Anchor Bible 36.)

Büchsel, F., 1964, s.v. 'Eijú, ó Ø̋v', in Theological Dictionary of the New Testament, p. 399, Logos Bible Software. (TDNT).

DeSilva, D.A., 1995, Despising shame. Honor discourse and community maintenance in the Epistle to the Hebrews, Scholars, Atlanta, GA. (SBL Dissertation Series 152.)

DeSilva, D.A., 2000, Perseverance in gratitude. A sosio-rhetorical commentary on the Epistle 'to the Hebrews', Eerdmans, Grand Rapids, MI.

Filson, F.V., 1967, 'Yesterday.' A study of Hebrews in the light of chapter 13, SCM, London. (Studies in Biblical Theology. Second Series 4.)

Grässer, E., 1992a, 'Die Gemeindevorsteher im Hebräerbrief', in E. Evang \& M. Merk (Hrsgs.), Aufbruch und Verheissung. Gesammelte Aufsätze zum Hebräerbrief, pp. 213-230, De Gruyter, Berlin. (Beihefte ZNW 65.)

Grässer, E., 1992b, 'Das wandernde Gottesvolk. Zum Basismotiv des Hebräerbriefes', in E. Evang \& M. Merk (Hrsgs.), Aufbruch und Verheissung. Gesammelte Aufsätze zum Hebräerbrief, pp. 231-250, De Gruyter, Berlin.

Grässer, E., 1992c, “"Wir haben hier keine bleibende Stadt” (Hebr 13, 14). Erwägungen zur christlichen Existenz zwischen den Zeiten', in E. Evang \& M. Merk (Hrsgs.), Aufbruch und Verheissung. Gesammelte Aufsätze zum Hebräerbrief, pp. 251-264, De Gruyter, Berlin.

Guthrie, G.H., 2003, 'Hebrews' use of the Old Testament: Recent trends in research', Currents in Biblical Research 1(2), 271-294. http://dx.doi. org/10.1177/1476993X0300100208

Hamm, D., 2004, "Praying "regularly" (not "constantly"): A note on the cultic background of dia pantos at Luke 24:53, Acts 10:2 and Hebrews 9:6, 13:15', Expository Times 116(2), 50-52. http://dx.doi.org/10.1177/001452460411600203

Hegermann, H., 1988, Der Brief an die Hebräer, Evangelische Verlagsanstalt, Berlin. (ThHzNT 16.)

Hübner, H., 1995, Biblische Theologie des Neuen Testaments, Band 3, Hebräerbrief, Evangelien und Offenbarung; Epilegomena, Vandenhoeck \& Ruprecht, Göttingen.

Hughes, P.E., 1977, A commentary on the Epistle to the Hebrews, Eerdmans, Grand Rapids, MI.

Hunsinger, G., 2012, 'The same; only different: Karl Barth's interpretation of Hebrews $13: 8^{\prime}$, in G. Hunsinger (ed.), Thy word is truth. Barth on Scripture, pp. 112-124, Eerdmans, Grand Rapids, MI.

Isaacs, M.E., 1997, 'Hebrews 13.9-16 revisited', New Testament Studies 43, 268-284. http://dx.doi.org/10.1017/S0028688500023262

Johnson, L.K., 2003, 'The scriptural world of Hebrews', Interpretation 57(3), 237-250. http://dx.doi.org/10.1177/002096430005700302

Johnson, R.W., 2001, 'Going outside the camp. The sociological function of the Levitical critique in the Epistle to the Hebrews', Journal for the Study of the New Testament, suppl. ser. 209.

Jones, P.R., 1985, 'A superior life: Hebrews 12:3-13:25', Review and Expositor 82(3), 391-405. http://dx.doi.org/10.1177/003463738508200307

Klauck, H-J., 2006, 'Moving in and moving out: Ethics and ethos in Hebrews', in J.G. van der Watt (ed.), Identity, ethics, and ethos in the New Testament, pp. 417-443, De Gruyter, Berlin. (Beihefte ZNW 141.)

Koester, H., 1962, '“Outside the camp": Hebrews 13.9-14', Harvard Theological Review 55(4), 299-315. http://dx.doi.org/10.1017/S0017816000007951

Lane, W.L., 1991, Hebrews 9-13, Word Books, Dallas, TX. (WBC 47B.)

Loader, W.R.G., 1981, Sohn und Hoherpriester. Eine traditionsgeschichtliche Untersuchung zur Christologie des Hebräerbriefes, Neukirchener Verlag, Neukirchen-Vluyn. (Wissenschaftliche Monographien zum Alten und Neuen Testament 53.)

Michel, O., 1966, Der Brief an die Hebräer, 12. Aufl., Vandenhoeck \& Ruprecht, Göttingen. (KEK 13.) 
Moffat, J., 1924, A critical and exegetical commentary on the Epistle to the Hebrews, T\&T Clark, Edinburgh. (ICC.)

Saunders, L., 1979, “'Outside the camp”: Hebrews 13', Restoration Quarterly 22(1-2), 19-24.

Steyn, G.J., 2006, 'The occurrence of Psalm 118 (117):6 in Hebrews 13:6: Possible liturgical origins?', Neotestamentica 40(1), 119-134.

Steyn, G.J., 2012, 'The ending of Hebrews reconsidered', Zeitschrift für die neutestamentliche Wissenschaft und die Kunde der älteren Kirche 103(2), 235253. http://dx.doi.org/10.1515/znw-2012-0015

Thompson, J.W., 2011, 'Insider ethics for outsiders: Ethics for aliens in Hebrews', Restoration Quarterly 53(4), 207-219.

Walker, P., 1994, 'Jerusalem in Hebrews 13:9-14 and the dating of the Epistle', Tyndale Bulletin 45(1), 39-71.
Wedderburn, A.J.M., 2004, "The "letter" to the Hebrews and its thirteenth chapter', New Testament Studies 50, 390-405. http://dx.doi.org/10.1017/ S0028688504000220

Wedderburn, A.J.M., 2005, 'Sawing off the branches: Theologizing dangerously ad Hebraeos', Journal of Theological Studies NS 56(2), 393-414. http://dx.doi. org/10.1093/jts/fli103

Weiss, H-F., 1991, Der Brief an die Hebräer, 15. Aufl., Vandenhoeck \& Ruprecht, Göttingen. (KEK 13.)

Willis, T.M., 1994, '“Obey your leaders": Hebrews 13 and leadership in the church', Restoration Quarterly 36(4), 316-326.

Woschitz, K.M., 2000, 'Christus - (gestern, heute), und derselbe in alle Ewigkeit', Renovatio 56(2), 77-86.

Young, N.H., 2002, '"Bearing his reproach" (Heb 13.9-14)', New Testament Studies 48, 243-261. http://dx.doi.org/10.1017/S0028688502000176 